\title{
Impacts of Climate Change on Natural Hazards and Land Use in the Saas and Zermatt Valleys (Switzerland)
}

\section{Markus Stoffel, Fribourg}

\section{Introduction}

Alpine valleys - such as the Saas and Zermatt Valleys in the Valais Alps (Switzerland) - have always been influenced by climatic fluctuations and natural catastrophes. The landscape is clearly marked by glacial, hydrological (i.e. torrential flooding) and gravitational processes (i. e. landslides, rockslides). Natural hazards have also strongly influenced the settlement of these steep and narrow valleys: as «safe» space was (and still is) rather rare, areas suitable for village development were limited, keeping the number of inhabitants at a moderate level.

In the middle of the 19th century, English tourists discovered the Zermatt and Saas Fee regions. Today, tourism is the main source of income for the area and the formerly predominant agriculture has lost its importance. As a result, the numbers of permanent residents and holiday homes have rapidly increased. However, space safe for construction has remained constant, and the growth of these villages has already (or will soon have) reached its limits. Considering the possibility of climate change, land use planners will have to take these physical restrictions into account when defining developmental zones in the future. Climate change can affect land use planning in two different ways:

- First, the spatial requirements of current land use could be modified by climate change, new needs could arise.

- Second, climate change could affect the nature and magnitude of natural hazards. Depending on whether the risk of danger increases or decreases, space will either be lost or won.

Thus, the prospect of climate change leads to new insecurities. The resulting conflicts will be especially serious when existing uses are impinged upon by new or modified potentials of natural dangers. Predictions of possible changes are, however, difficult to make and are always linked with major uncertainties. For this reason, it is important to note that the assessments presented in this paper may be possible, in some cases even probable, but they are not «real time» predictions. Land use planning on the other hand has a direct influence on future decisions and is consequently of economic importance. This paper, therefore, focuses on the following two aspects:
- The analysis and evaluation of existing policies defining danger zones and protecting civilians. In particular the validity and appropriateness of the policies are examined. At the same time, it is possible to build up a nearly complete record of natural hazard areas in the study region.

- Assessment of the consequences of predicted climate change on natural hazards. This incorporates the definition of potential high risk areas and an analysis of the extent of these zones.

The final report of this diploma thesis (STOFFEL 1999 a) was sponsored and published by the Swiss National Research Program 31 «Climate change and natural hazards» (BLOETZER et al. 1998).

\section{Geography of the Saas and Zermatt valleys}

The Saas and Zermatt valleys are both deep mountain valleys in the Valais Alps (Switzerland). Surrounded by some of the highest peaks in the alpine arc, the test region $\left(520 \mathrm{~km}^{2}\right)$ is strongly glaciated. The main source of income for the population of 16810 is tourism: Nearly 1.5 million tourists are accommodated annually in the tourist centres of Zermatt (Matterhorn) and Saas Fee.

Natural hazards are a part of life in the test region, limiting «safe» space on the valley floors. Nearly all villages in the Saas and Zermatt Valleys are threatened by snow avalanches, rockfalls, land- or rockslides, floods and debris flows. Most of these events are initiated at high altitudes (Highest peak: Dom Peak 4545m above sea level), crashing several hundreds of metres down into the steep and narrow valleys (Lowest site: Stalden $710 \mathrm{~m}$ above sea level). Land use planning is, therefore, rather limited by the availability of suitable space.

\section{Land use planning and natural hazards in Switzerland}

\subsection{Legal basis}

The goal of land use planning is to guarantee an expedient and economical use of the soil and an orderly development of the country. The Swiss Government has drafted constitutional articles, several federal laws, statutes and decrees to enforce these targets - forming the Land Use Planning Act of 1979. It defines the principles for an appropriate development of the country but gives the Cantons the liberty to define legal articles at the can- 


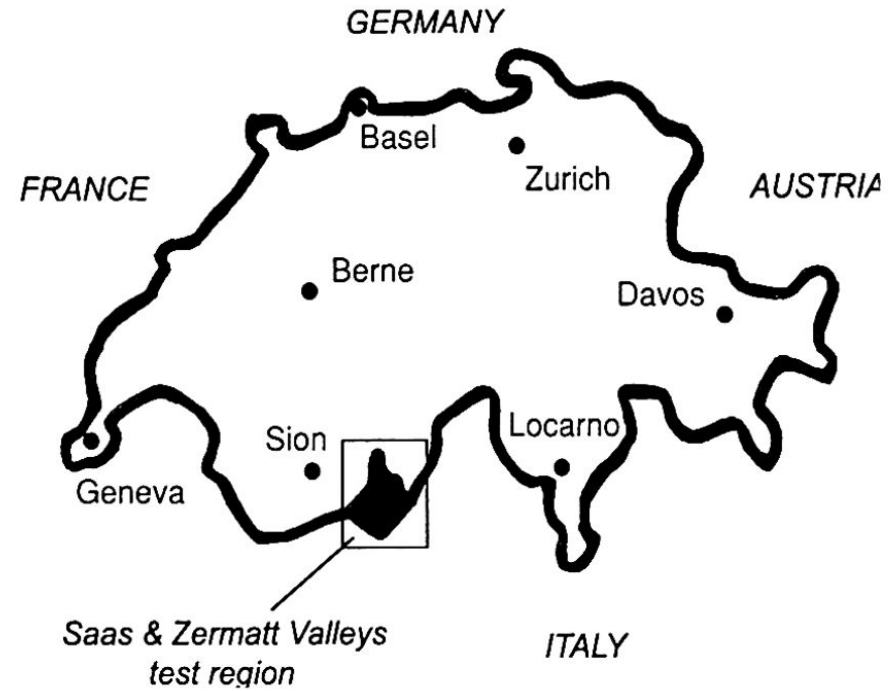

Fig. 1: Geographical location of the Saas and Zermatt Valleys (Valais, Switzerland)

Lage des Saas- und Nikolaitals (Wallis, Schweiz) Localisation des vallées de Saas et de Zermatt (Valais, Suisse)

tonal level. The land use planning statute thus has a strong local basis. In spite of the cantonal and communal differences, a standard procedure at three different levels is always followed (BLOETZER et al. 1998):

- At the level of the cantonal general plan, large areas, supraregional functions and criteria for the zoning plan are defined.

- At the level of the communal zoning plan, uses and limitations with obligations for the landowners are determined.

- Finally, the issuance of building permits enables the authorities to control and supervise imposed obligations and restrictions.

In addition, one has to consider that land use planning measures have long-term effects and that once residential or industrial zones have been developed, the land use is practically irreversible. For this reason, the constitutional principles of law and order need to be respected, whenever there are interventions in private property.

\subsection{Hazard mapping}

At the cantonal, communal and individual planning levels, natural dangers are taken into account in several ways. The Federal Land Use Planning Act of 1979 - as well as the Federal Forest Act, the Federal Hydraulic Engineering Act (both of 1991) and their corresponding decrees and explanations clearly define guidelines for drawing up catastrophe catasters of past events as well as lists of endangered areas. On the basis of the catasters and lists, simulations and calculations are car- feet above sea level

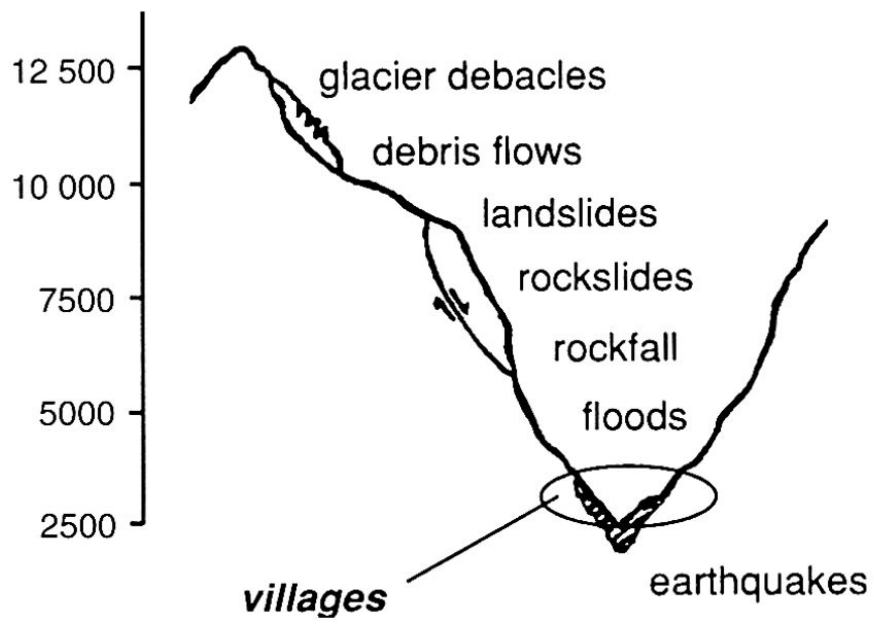

Fig. 2: Mostly all catastrophic events in the Saas and Zermatt Valleys start at high elevation sites to reach the narrow valley floor; note the position of the villages often situated on mountain torrent alluvial fans Eine grosse Zahl katastrophaler Ereignisse des Saasund des Nikolaitals finden ihren Ursprung in hohen Lagen, um alsdann den engen Talboden zu erreichen; die Dörfer der untersuchten Region befinden sich häufig auf Wildbach-Schuttkegeln

La plupart des événements catastrophiques de la région de Saas et de Zermatt se déclenchent à haute altitude pour atteindre finalement le thalweg enserré des vallées; noter la fréquente localisation des villages sur les cônes alluviaux de torrents (de montagne) latéraux

ried out, the results of which are presented in hazard maps distinguishing between three degrees of danger (see Figure 3).

Every municipality has to map hazardous regions before defining future residential or industrial zones. This way, hazard mapping helps guarantee long-term planning measures: new buildings may only be constructed in areas where they are exposed to no or little danger. After major events, the hazard maps have to be revised and adapted to the new situation. The Grossgufer rockslide (1991) - involving 30 million $\mathrm{m}^{3}$ of rock - buried 33 buildings near the village of Randa (Zermatt Valley). Reclassification of residential zones was necessary after this event (STOFFEL 1999 a).

\section{Changing natural hazards by climate changes}

\subsection{Test region climate of the 21st century}

In its Climate Change 1995 report, the Intergovernmental Panel on Climate Change (IPCC) estimated that the global mean surface air temperature would increase by about $2^{\circ}$ Celsius between 1990 and 2100. In the south- 
ern part of the Swiss Alps, the increase could be as high as 0.5 to $1.5^{\circ} \mathrm{Kelvin}$ in winter and 2 to $4^{\circ}$ Kelvin in summer by 2050 . Precipitation is likely to decrease during the summer $(-10 \%)$ and increase during the winter season (+10\%) (IPCC 1996; OHMURA, BENISTON et al. 1996).

Considering the probability of the climate change forecast, those involved in planning questions will have to take this new aspect into consideration when allocating uses to available areas, particularly as a changing climate can influence the risk of natural hazards. Conflict potential is high where existing uses are affected negatively by new or modified potentials of natural dangers. Therefore, climate change and the resulting modification of natural hazards lead to new insecurities.

\subsection{Modified natural hazards}

Warmer temperatures and a greater occurrence of individual climatic extremes will probably influence some natural hazards in the Saas and Zermatt Valleys more than others. Rockslides, large landslides and snow avalanches are not expected to be affected much by climatic variations, on the other hand the occurrence of flashfloods, glacier debacles and cryospheric debris flows could easily be more frequent (BADER \& KUNZ 1998), particularly in the late summer and in autumn (Zimmermann et al. 1997a, b, RebeteZ et al. 1997). Floods in the Saas and Zermatt Valleys often occur after heavy summer thunderstorms or when extended precipitation touches on the dry, leeward areas affected by foehn. The occurrence of these climatic events appears to be increasing, causing major damage most recently in 1987 and 1993. Maps of detailed flood risk areas are in preparation.
Although less common than floods or debris flows, the destructive capacity of fast-moving slides of large ice masses known as glacier debacles on buildings and infrastructure is high. The Allalin glacier debacle (Saas Almagell) of 1965 buried 88 Mattmark dam constructors and completely destroyed all of the cabins. To avoid a similar disaster, many glaciers in the Swiss Alps are regularly controlled, making the risk of unexpected slides rather low.

An increase of the present temperatures will probably lead to a partial thawing of the uppermost layers of permafrost soils and rock glacier ice at higher elevations. As a consequence, loose talus lose the cohesive effect of the ice («ice-concrete»), and debris flow is made possible. Historical records indicate that the events in recent times have increased at an alarming rate. It may thus be assumed that the number and volume of future debris flows reaching the alluvial fans and the villages of the Saas and Zermatt Valleys will increase. As a result, less land is available for development. To be able to make a clearer picture of future events, general studies on permafrost modification in the zone of origin will be necessary. In addition, geomorphological research of the alluvial fans could cast more light on possible debris flow paths.

\section{Conclusions}

1. The mandate to assess and eliminate danger zones as far as possible, as well as to restrict development to areas of low risk gives Swiss land use planning authorities an adequate system to provide optimal safety conditions. Nevertheless, a certain element of inse-

\footnotetext{
What do the different colors in natural hazard risk maps mean in terms of «danger»?

red: $\quad$ people and animals are seriously endangered both inside and outside buildings $=>$ no constructions allowed in this area

blue: $\quad$ people and animals are seriously endangered outside buildings

$\begin{array}{ll} & =>\text { limited construction possible (reinforced concrete, small } \\ \text { yellow: } & \text { people and animals are lightly endangered outside buildings }\end{array}$

white: $=>$ no restrictions
}

For buildings with a temporary or permanent concentration of people (e. g.: schools, churches), special regulations are applicable. Such construction is only possible in the yellow or the white zones.

Fig. 3: Regulations on endangered areas and building space for land use planning purposes in Switzerland Empfehlungen des Bundes zur Bezeichnung von Gefahrenzonen und damit verbundene Folgen

für die Raumplanung

Recommandations fédérales pour l'établissement des zones à risque et conséquences pour

l'aménagement du territoire

(BUWAL, BWW \& BRP 1998, 1997; BFF \& EISLF 1984) 
curity in predicting hazardous areas will always exist, and hazard mapping will always be an ongoing process.

2. The predictions of possible modifications to natural hazard patterns due to climatic change is a real challenge for land use planners, particularly as the predictions are not easy to make and carry a great degree of uncertainty. As a precaution, «buffer areas» or zones of potential high risk should be allowed for («Gefahrenerwartungszone»). The definition of zones of potential high risk has two advantages: first, construction in such areas can be delayed while carried out elsewhere; second, areas are clearly demarcated for careful observation and risk development study (STOFFel 1999 b).

3. Land use planning is not expected to change fundamentally due to modified climate conditions, particularly as the prediction of potential natural dangers is at present difficult enough, perhaps even more difficult than calculating the effects of climate change on these natural processes. Nevertheless, in order to ensure present and future safety of the population it is absolutely necessary to take potential problem areas into account when assigning new land uses.

4. Far more important than the definition of legal principles at the community level is a clear and logical description of the impending danger. If the local population is aware of the possible danger and is able to understand why certain measures have to be taken, it will be easier to implement the appropriate measures required by existing law. This link to the population is all the more important if precautionary measures are to be taken with regard to new dangers and those influenced by climatic variation.

5. Risk communication is, therefore, a central element of natural hazard control. Particularly the inhabitants of mountain regions are used to living with natural dangers. They are aware that absolute security and predictions free of mistakes are not possible. As the local population on the one hand has to support and accept risk management and on the other hand has to make a living in situ, it should be more strongly involved in the decision making process. It should, therefore, be a central task of science to describe possible changes in a clear and intelligible way, thus ensuring a good basis for communication between all parties involved.

\section{Acknowledgements}

This paper partly draws on the work of the reserach group «Climate Change and Natural Hazards in Land Use Planning» under the National Research Program 31 «Climate Change and Natural Hazards». The contribution of the following project members is acknowledged: Werner Bloetzer, Visp; Dr. Thomas Egli, St. Gallen; Dr. Armin Petrascheck, Biel and Joseph SAUTER, Chur. In addition, the author would like to thank all researchers of the National Research Program 31, especially Dr. PIerre KunZ, University of Geneva, Dr. Markus ZimmermanN, Bern and Profs. Michel Monbaron and Martin Beniston, University of Fribourg.

\section{Literature Cited}

BADER, S. \& P. KUnZ (1998): Climat et risques naturels - La Suisse en mouvement. - = Final Report National Research Program 31, Zürich: 1-312

BFF \& EISLF (1984): Richtlinien zur Berücksichtigung der Lawinengefahr bei raumwirksamen Tätigkeiten. - Bern: EDMZ.

Bloetzer, W., Egli, T., Petrascheck, A., Sauter, J. \& M. STOFFEL (1998): Klimaänderung und Naturgefahren in der Raumplanung - Methodische Ansätze und Fallbeispiele. $-=$ Final report National Research Program 31, Zürich, vdf: 1-200.

BUWAL, BWW \& BRP (1998): Naturgefahren; Berücksichtigung der Massenbewegungsgefahren bei raumwirksamen Tätigkeiten. - Bern, EDMZ.

BUWAL, BWW \& BRP (1997): Naturgefahren; Empfehlungen zur Berücksichtigung der Hochwassergefahren bei raumwirksamen Tätigkeiten. - Bern, EDMZ. IPCC (1996): Climate Change 1995: The Science of Climate Change. Contribution of Working Group I to the Second Assessment Report of the Intergovernmental Panel on Climate Change. - Cambridge: Cambridge University Press.

Haeberli W., Kä̈̈в, A., Hoelzle, M., Boesch, H., FunK, M., Vonder Muehll, D. \& F. Keller (1999): Eisschmelzen und Naturkatastrophen im Hochgebirge. - = Final report National Research Program 31, Zürich, vdf: $1-150$.

Ohmura, A., Beniston, M., Rotach, M., Tschuck, P., WILD, M. \& M.R. MARINUCCI (1996): Simulation of Climate Trends over the Alpine Region. - = Final report National Research Program 31, Zürich, vdf: 1-197.

Rebetez, M., Lugon, R. \& P.-A. Baeriswyl (1997): Climatic Change and Debris Flows in High Mountain Regions: The Case Study of the Ritigraben Torrent (Swiss Alps). - In: Climate Change 36: 371-389.

Stoffel, M. (1999 a): Klimawandel als Herausforderung für die Raumplanung der Vispertäler. - = Diploma thesis, Department of Geography, University of Fribourg, Fribourg: 1-89.

STOFFel, M. (1999 b): Géomorphologie et aménagement du territoire. - In: Research Report 1998, Institut de Géographie, Université de Fribourg, Fribourg: 3637.

Zimmermann, M., Mani, P., Gamma, P., Gsteiger, P., Heiniger, O. \& G. HunZiker (1997 a): Murganggefahr und Klimaänderung - ein GIS-basierter Ansatz. - = Final report, National Research Program 31, Zürich, vdf: $1-162$. 
ZimmermanN, M., Mani, P. \& H. Romang (1997 b): Magnitude-frequency aspects of alpine debris flows. In: Eclogae Geol. Helv. 90: 415-420.

\section{Summary: Impacts of Climate Change on Natural Hazards and Land Use in the Saas and Zermatt Valleys (Switzerland)}

The aim of Swiss land use planning is to guarantee an expedient and economical use of the land and an orderly development of the country. Therefore, land use planning has to designate areas suitable for optimal economic development. The possiblility of climate change poses a special challenge for land use planners. This paper examines the implications of environmental change resulting from climate change and anticipates new zones of conflict between existing and future land uses in the Saas and Zermatt Valleys (Valais, Switzerland). Differences between the "real-time" decisions of planners and the possible development of risks and changes predicted by scientists are key factors examined in this paper. Furthermore, this paper investigates the legal implications of land use planning under conditions of climatic uncertainty. Particular emphasis is given to the various ways natural dangers can be taken into account at the levels of the "cantonal" general plan, communal zoning plan and the issueing of building permits. Finally, this paper recommends the establishment of abuffer areasn or zones of potential high risk as precautionary measures and highlights the fundamental necessity of risk communication for natural hazard control.

\section{Zusammenfassung: Auswirkungen des}

Klimawandels auf die Naturgefahren und die

Raumplanung des Saas- und Nikolaitals (Schweiz)

Es ist die Aufgabe der schweizerischen Raumplanung. eine zweckmässige und haushälterische Nutzung des Bodens und eine geordnete Besiedlung des Landes sicherzustellen. Daher muss die Raumplanung für die Planungsperioden die räumlichen Voraussetzungen für eine optimale Wirtschaftsentwicklung schaffen. Als zusät/licher Faktor ist nun nebst der Wirtschaftsentwick. lung auch die sich anbahnende Veränderung des Klimas zu berücksichtigen. Die vorliegende Arbeit versucht. das aktuelle Gefahrenbild in der Testregion "Vispertialern (Saas- und Nikolaital. Wallis, Schweiz) zu erläutern und auf mögliche Veränderungen des Gefahrenpotentials hin $z$ untersuchen. Dabei muss aber immer beachtet werden. dass die aufgedeigten Entwicklungen zwar möglich. mitunter gar wahrscheinlich sind. jedoch keine Vorhersagen in "Echtecit. darstellen. Im Gegensatz dazu stellen raumplanerische Beschlusse Entscheide in "Echtzeit" dar und haben somit schwerwiegende wirtschaftliche Konsequen/en. Deshalb sollen bei möglichen künftigen Gefahrenveranderungen bereits heute vorsorgliche Erweiterungen von Gefahrengebieten als "Gefahrenerwartungs-» oder Puffersonen bezeichnet werden, um Konflikte in Zukunft so gut wie möglich zu verhindern. Schliesslich spielt auch der Kontakt zwischen Experten und der Bevölkerung eine wichtige Rolle. Die Risikokommunikation ein zentrales Element im Umgang mit Naturgefahren darstellt.

\section{Résume : Impacts du changement climatique sur les risques naturels et l'aménagement du territoire dans les vallées de Saas et de Zermatt (Suisse)}

L'aménagement du territoire a comme tâche de garantir une affectation appropriée et économe du sol et une occupation rationnelle du territoire. Dans ce but, il doit créer les conditions-cadre à un développement économique optimal, déjà lors des périodes de planification. Les changements climatiques représentent une préoccupation actuelle d'imponance croissante, devant être prise en compte par les aménagistes en complément aux aspects économiques de l'aménagement du territoire. Le but de ce travail fut de démontrer et d'analyser les dangers existants ainsi que les "dangers futurs" d'un climat plus chaud dans les Vallées de la Viège (Vallée de Saas et de Zermatt, VS, Suisse). En outre, les résultats doivent être mis en relation avec les documents qui régissent l'aménagement du territoire (p. ex.: plans d'affectation), sans oublier que ces modifications peuvent être possibles, parfois mème probables, mais quelles ne représentent pas des prognostics en atemps réelm. Par contre, les décisions au niveau de l'aménagment du territoire consistent toujours en des solutions en "temps réel» et ont comme telles des conséquences économiques majeures. Dans ce sens. ce papier propose pour l'instant une détermination de zones à danger du style "zone-tampon" ou zone de danger attendu. Cette politique prévoyante et restrictive doit ètre appliquée au niveau du plan directeur cantonal, au niveau du plan d'affectation communal et lors de l'autorisation de construction communale. Dans celte perspective, le dialogue à propos du risque entre spécialistes et population doit former un élément central dans le comportement face aux dangers naturels.

Dipl.-Geogr. Markus Stoffel, Institut de Géographie de l'Université de Fribourg / Geographisches Institut der Universitat Freiburg. Pérolles. $\mathrm{CH}-1700$ Fribourg.

e-mail: markus.stoffel (a unifr.ch

\section{Manuskripteingang/received/rentrée du manuscrit: 30.08. 1999}

Annahme :um DruckAccepted for publications acceptation à l'impression: 15.1.2000) 